\title{
Republicanismo: el lugar de la virtud
}

\author{
FÉLIX OVEJERO LUCAS \\ Universidad de Barcelona
}

RESUMEN. No hay caracterización del republicanismo que no mencione la virtud cívica. Sin embargo, no siempre es clara la ubicación de la virtud en el entramado de la filosofía política republicana. Tomaré como punto de partida la reflexión de Rawls. Su temor es que la defensa de lo que la democracia necesita, la virtud cívica, ponga en peligro la libertad. Es lo que llamaré el «problema (de Rawls) con la virtud». Un problema que, a su parecer, compromete seriamente al republicanismo. Por mi parte, intentaré mostrar que, en realidad, se trata de un problema del liberalismo que apunta directamente a una bien conocida tensión entre los derechos y la democracia, cuya única «solución liberal» pasa por atrincherar los derechos «frente a la democracia», excluyendo el compromiso ciudadano. En la segunda parte mostraré que el problema es real, pero que no afecta a todos los republicanismos y argumentaré que «el problema de Rawls» afecta, fundamentalmente, a aquel republicanismo que hace de la «realización ciudadana» su objetivo, que busca, por así decir, maximizar la virtud. No sucede lo mismo con aquel otro que otorga a la virtud un carácter instrumental. En la parte final precisaré esa idea de republicanismo que otorga tanto a la virtud como a la democracia un papel instrumental en lo que realmente importa: la libertad.

Palabras clave: republicanismo, Rawls, virtud cívica, liberalismo.
ABSTRACT. All characterizations of republicanism mention civic virtue. However, the location of virtue in republican political philosophy is not always clear. I will take as a starting point Rawl's reflection. His fear is that the defence of what democracy needs, civic virtue, can endanger freedom. This is what I will call (Rawl's) «problem with virtue». A problem which, in his view, seriously compromises republicanism. I will try to show that this is in reality a problem of liberalism which directly points to a very well known tension between rights and democracy, the only «liberal solution» of which amounts to entrenching rights «against democracy», excluding citizens' commitment. In the second part I will show that the problem is real, but that it does not affect all republicanisms, and I will argue that «Rawls' problem» fundamentally affects that republicanism which has as its objective «citizens's self-realization»; which tries, so to say, to maximize virtue. Things are not the same with that other republicanism which accords an instrumental value to virtue. In the last part I will define this idea of a republicanism which accords an instrumental role to virtue and democracy in that which really matters: freedom.

Keywords: republicanism, Rawls, civic virtue, liberalism. 


\section{Los republicanismos y la participación}

En un conocido paso de Political Liberalism Rawls intenta deslindar conceptualmente entre liberalismo y republicanismo. Sostiene que no hay diferencias fundamentales entre su idea del liberalismo y el republicanismo clásico, entendido como aquel comprometido con la tesis de que «si los ciudadanos quieren preservar sus derechos y libertades básicos (incluidas las libertades civiles que garantizan las libertades de vida cívica), deben también poseer en grado suficiente las «virtudes políticas» (como yo las he llamado) y mostrarse dispuestos a participar en la vida pública». Sin embargo, inmediatamente después, Rawls precisa que sí se reconoce en «una oposición fundamental con el humanismo cívico» otra versión de republicanismo, que califica como «aristotélica», según la cual «el hombre es un animal social, político incluso, cuya naturaleza esencial se realiza del modo más completo en una sociedad democrática en cuya vida política se dé una amplia y activa participación en la vida política. La participación no es alentada como un requisito necesario para la protección de las libertades básicas de la ciudadanía democrática, sino como una forma de bien entre otros, importante para muchas personas. Más bien, tomar parte en la política democrática se contempla como un lugar privilegiado de la buena vida» ${ }^{1}$.

Los juicios de Rawls resultan interesantes en más de un sentido. Por lo pronto, no busca la línea de demarcación entre liberalismo y republicanismo en una tesis normativa o en una propuesta institucional. En esto se diferencia de los filósofos políticos republicanos que han puesto el énfasis en ciertos principios (la libertad, el autogobierno) o formas institucionales (gobierno mixto, democracia deliberativa, participativa). Rawls relaciona el republicanismo, muy fundamentalmente, con la virtud cívica. Pero la virtud no aparece como un «principio». Las instituciones no se justifican porque promuevan la virtud; al contrario, la virtud se justifica porque contribuye al buen funcionamiento de las instituciones. En realidad, su tesis es empírica: sin virtud cívica, «sin una amplia participación en la política democrática por parte de un cuerpo ciudadano vigoroso e informado, y desde luego con un retiro generalizado a la vida privada, incluso las instituciones políticas mejor diseñadas acabarían en manos de quienes se proponen dominar e imponer su voluntad a través del aparato del Estado [...]. La salud de las libertades democráticas exige la activa participación de ciudadanos políticamente virtuosos» ${ }^{2}$. Esa tesis es la que juzga central en el republicanismo, tesis que comparte.

Sus divergencias con el otro republicanismo, en rigor, tampoco son normativas, sino - de nuevo- empíricas ${ }^{3}$. Atañe a una idea diferente de la

\footnotetext{
${ }_{1}$ Political Liberalism, pp. 206-207.

2 Ibid.

${ }^{3}$ Por más que diga es que una doctrina comprensiva. Sobre este punto, criticando la idea de que no hay oposición fundamental entre liberalismo político y republicanismo: J. Maynor, «Wit-
} 
naturaleza humana: la participación, que considera imprescindible para «la protección de las libertades básicas de la ciudadanía democrática», a su parecer, no respondería a, por decirlo clásicamente, «una naturaleza humana que despliega su ser más esencial en la actividad pública». Para Rawls, la participación, la virtud, sería puramente instrumental: el mejor modo de defender las propias libertades y evitar que las instituciones caigan en manos «de quienes se proponen dominar e imponer la propia voluntad a través del aparato de Estado». En ningún caso un rasgo de la naturaleza humana que se dé o quepa alentar. Él no comparte la tesis «según la cual el hombre es un animal social, incuso político, un animal cuya naturaleza se realiza del modo más completo en una sociedad democrática en la cual se dé una amplia y robusta participación política» ${ }^{4}$.

\section{$E l$ «problema (de Rawls) con la virtud»}

La caracterización rawlsiana del republicanismo no es original ${ }^{5}$. También otros sitúan la virtud en el centro de sus distinciones. El propio Wood, en su clásico trabajo, ya puso el acento en las disposiciones cívicas: «El sacrificio de los intereses individuales al bien superior del conjunto era lo esencial del republicanismo y constituyó para los americanos la inspiración, el ideal, de su Revolución» ${ }^{6}$. De todos modos, seguramente, su punto de partida, tal como está formulada la distinción rawlsiana entre los dos republicanismos, es más reciente y se inspira en el análisis de Quentin Skinner de los Discorsi de Maquiavelo. Según éste, sólo en la república libre se evitaría que los indi-

hout Regret: The Comprenhensive Nature of Non-domination», Politics, 2002, 22, 2. Más extendido está el punto de vista de quienes no ven diferencias: Ch. Larmore, «A Critique of Philip Pettit's Republicanism», 35 Nous-Supplement: 2001; R. Dagger, Richard, Civic Virtue: Rights, Citizenship and Republican Liberalism, Oxford, Oxford U. P., 1997; N. Buttle, «Liberal Republicanism», Politics, 1997, 17, 3.

${ }^{4}$ Political Liberalism, p. 206.

${ }_{5}^{5}$ Quiero precisar que esta circunstancia - la extensión y el peso de las tesis recogidas en el párrafo anterior - es la que disculpa la pequeña injusticia que puedo haber cometido con Rawls. Hay más Rawls que el que acabo de reconstruir. Por ejemplo, el que sostiene que: «(en una sociedad bien ordenada) (los ciudadanos) comparten un fin político básico y un fin altamente prioritario, a saber: el fin de apoyar las instituciones justas y de hacerse en consonancia justicia mutuamente, por no mencionar los otros fines que también deben compartir y realizar a través de la cooperación política. Más aún en una sociedad bien ordenada la justicia política está entre los objetivos más básicos de los ciudadanos, por referencia a los cuales expresan la clase de opiniones que quieren ser», La justicia como equidad, Barcelona, Paidós, 2002, p. 263. Pero no es menos cierto que los dos Rawls no conviven cómodamente. Una incomodidad que tiene, a mi parecer, su raíz última en las tensiones entre su liberalismo y su compromiso democrático, sobre la que volveré. A la vez, seguramente, esa misma circunstancia y su enorme honestidad intelectual están en el origen de su aguda percepción de los problemas que nos ocupan.

6 The Creation of American Republic 1776-1787, Chapel Hill: University of North Carolina Press, 1969, p. 53. 
viduos ambiciosos, los intrigantes grandi, «especialmente si consiguen ser elegidos [...] gobiernen conforme a sus propios deseos». Para ello se requiere que «todo el cuerpo de ciudadanos supervise permanentemente y participe en el proceso político». Los ciudadanos, para preservar su libertad y, en general, para que sus intereses sean tomados en consideración, han de evitar una desigual distribución de poder, han de asegurarse una república máximamente democrática. Defender la «libertad de la república» es el mejor modo de asegurar la «libertad de cada uno» ${ }^{7}$. En ese sentido, «sólo podemos disfrutar de la máxima libertad individual si no la anteponemos a la búsqueda del bien común» ${ }^{8}$. Es ése el republicanismo clásico de Rawls, el que juzga defendible.

La defensa de la libertad de todos se hace por interés en la libertad propia ${ }^{9}$. En realidad, la república se sostiene sin virtud, incluso desde cierto pesimismo antropológico. Nadie hace nada por nadie: los poderosos procuran su propio beneficio; el pueblo no quiere ser dominado ${ }^{10}$. Las dificultades también arrancan de ahí: de ese pesimismo, de la escasa disposición cívica. El problema es, en principio, conceptual, pero, relacionado con él, hay otro fundamental para la estabilidad de la democracia republicana (y, en este punto, rawlsiana).

El problema conceptual atañe a la calificación como virtuoso del comportamiento de los ciudadanos. No parece muy razonable llamar «virtuoso» a un comportamiento interesado o instrumental. La virtud se corresponde, en una caracterización no muy exigente, con «la acción correcta por las razones correctas» ${ }^{11}$. Esto excluye, por definición, el comportamiento «virtuoso»

${ }^{7}$ La argumentación de Maquiavelo se refiere sobre todo a «la libertad de la república». Es la veta que han explotado los teóricos del republicanismo como no dominación. Como se verá, el vínculo de esa idea con la de participación no es inmediato. De todos modos, una mirada atenta a la obra del florentino permite reconocer las propuestas democráticas, de control «directo», más allá de las elecciones periódicas, cfr. J. Mccormick, «Machiavellian Democracy: Controling Elites with Ferocius Populism», American Political Science Review, núm. 95, 2, 2001

${ }^{8}$ Q. Skinner, «Acerca de la justicia, el bien común y la prioridad de la libertad», La Política, núm. 1, 1996, pp. 146-147. Skinner ha documentado en diversos trabajos la presencia de estos argumentos en los Discorsi (libro II, 2).

9 Cuando no directamente en razones más «materiales». Son continuas las alusiones al «aumento de la riqueza», a que, en la república libre, «las riquezas se multiplican en mayor número, tanto las que proceden de la agricultura como de las artes, pues cada uno se afana gustosamente y trata de adquirir bienes que, una vez logrados, está seguro de poder gozar», cfr. Discursos sobre la Primera Década de Tito Livio, Madrid, Alianza, 1987 (libro II, 2, pp. 185 y 191). Le cuadran perfectamente las opiniones de Marx en La cuestión judia: «los emancipadores políticos reducen la ciudadanía, la comunidad política, a mero medio para la conservación de derechos humanos; el ciudadano es mero servidor del hombre egoísta, el ámbito en que el hombre se comporta como comunidad queda degradado por debajo del ámbito en que se comporta como ser parcial [...] la vida política se declara un mero medio, cuyo fin es la vida de la sociedad burguesa», Marx y Engels, Obras de Marx y Engels, OME-5, Barcelona, Crítica, 1978, pp. 196-197.

10 Un repaso de los distintos matices terminológicos de Maquiavelo respecto a las motivaciones «egoístas», cfr. R. Price, «Self-love, "egoism" and ambizione in Machiavelli's thought», History of Political Thought, IX, núm. 2, 1988.

11 R. Audi, «Acting From Virtue», Mind, núm. 415, 1995. 
por razones ulteriores, porque «resulta conveniente» (lo que no impide, por supuesto, que tenga consecuencias «convenientes», sólo que tales consecuencias no están en el origen del comportamiento).

Pero es que, además, y con eso ya nos acercamos al otro problema, al importante, cuando la virtud es «instrumental», cuando el buen comportamiento del ciudadano responde a que le «resulta conveniente», a que «le conviene», entonces ya no cumple su saludable función en el mantenimiento de la libertad de la república, en la libertad de todos, en la estabilidad de la democracia que preocupa a Rawls. Ello es consecuencia del carácter público de la acción política, que no se aviene con una participación «instrumentalmente» virtuosa. No parece discutible la tesis de Maquiavelo (y Skinner y Rawls) según la cual sólo en una república libre pueden los ciudadanos ser libres, sólo quienes viven bajo un gobierno republicano pueden realizar sus objetivos y perseguir sus metas personales. Ahora bien, sucede que la ciudadanía no admite grados, que los derechos que conlleva no se pueden distribuir según el grado de «virtud» de cada cual ${ }^{12}$. Y ahí aparece el problema: dado el carácter público de las leyes, dado que la libertad es indivisible, que no hay modo de asegurar protección o igualdad de poder a unos sin hacerlo a todos y que, por tanto, una vez se dispone de la libertad, no hay modo de distinguir entre quienes luchan por ella y quienes no, ¿qué razones tendrían los ciudadanos para defender la libertad de la república de la que, en tanto ciudadanos, no pueden ser excluidos? Si es el caso, que lo es, que las leyes justas y la sociedad libre son bienes públicos, que cuando están a disposición de uno lo están a disposición de todos, ¿por qué los ciudadanos habrían de defender la libertad de la república? ¿No les resultaría más provechoso procurar sus objetivos particulares y dejar a los otros la preservación de la libertad de todos que, inevitablemente, será la libertad de cada uno, su libertad? Ahora bien, en ese caso, ya sabemos lo que sucederá: si todos actúan así, no habrá libertad para nadie, no habrá república libre. A cada cual, lo que verdaderamente le «resulta conveniente», dado el carácter inevitable de bien público de la libertad de la república, es dejar en manos de los otros su defensa. Pero, claro es, cuando todos piensan lo mismo, nadie procura la libertad y la república fracasa ${ }^{13}$. Le hemos visto admitirlo al propio Rawls: sin participación, de poco sirven las mejores instituciones democráticas. Lo mismo, por cierto, que pensaba Rousseau: «En cuanto el servicio público deja de ser la principal ocupación de los ciudadanos y prefieren servir con su bolsa antes que con su persona, el Estado se encuentra próximo a su ruina» (Contrato social, III, XV).

12 Rawls mismo subraya esa condición de «bien publico» de la ciudadanía: «el estatus fundamental tiene que ser el de la ciudadanía parigual, un status que todos poseen, en su calidad de personas iguales y libres», La justicia como equidad, op. cit., p. 179.

13 Nos encontramos en una situación opuesta a la mano invisible del mercado. En éste el «bienestar» de todos se asegura cuando cada uno procura su propio bienestar, objetivo para el que cada uno, por egoísta, tiene incentivos; por el contrario, en la imagen de Maquiavelo, el bienestar de uno mismo se obtiene cuando se asegura el bienestar de todos. 
El problema desaparecería si los ciudadanos fueran «naturalmente» virtuosos, si la libertad de todos formase parte sus objetivos, si estuvieran interesados en la libertad de la república, no sólo en «su» libertad. Precisamente lo que, en principio, sucede con el «republicanismo cívico» que Rawls descalifica. En éste es importante para cada uno asegurar la libertad de los otros. De modo que, aun si cada uno pudiese sentirse tentado a dejar a los otros el cuidado de la república, no lo hace porque para él participar es como respirar: inevitable. No hay problema de acción colectiva porque para todos la participación es un modo de vida, el más importante, es la actualización de lo mejor de sí mismo. La libertad de la república es una simple externalidad de su práctica de vivir, de su propia libertad. La libertad, por supuesto, se justifica normativamente; pero su búsqueda está en «la naturaleza humana», como una capacidad (bien) dispuesta a ser ejercida, desarrollada.

Rawls, y no sólo él, parece considerar que «la respuesta aristotélica» exigiría la intromisión del Estado en la vida de los ciudadanos y, en ese sentido, resulta incompatible con principios elementales de libertad individual. No estoy seguro de ello. Creo que «el problema del Rawls con la virtud» no es un problema que afecte, necesariamente, al republicanismo; al menos, como intentaré mostrar, a todos los republicanismos. Su «problema» es, sobre todo, una «dificultad liberal». Su punto de arranque es la discontinuidad entre la ética privada y la virtud cívica, entre la idea de bien de cada cual, que es la que «compromete» la vida de los individuos, y las razones para actuar como ciudadanos ${ }^{14}$. La expresión más consumada de esa dificultad es la tensión - siempre sobre el trasfondo de la ausencia de compromiso ciudadano- entre los derechos - que aseguran la libertad - y la democracia: la falta de virtud convierte a la democracia en una amenaza para los derechos. Recordemos brevemente la raíz de esa tensión.

\section{El liberalismo y la virtud ${ }^{15}$}

El liberalismo se puede ordenar conceptualmente a partir del principio de maximización de la libertad negativa: A es libre de hacer X si nadie le impide -0 le coarta para - hacer X. Una sociedad libre debe minimizar las intromisiones en la vida de los ciudadanos. Éstos no deberían estar atados por otras obligaciones que aquellas que asumen contractualmente. El paradigma del ejercicio de la libertad liberal es la relación de intercambio, relación en la que yo me comprometo a hacer A (realizar un trabajo, entregar un bien, pagar un dinero) a cambio de tu compromiso de hacer B. Esa relación,

${ }_{14}$ En contraste con «el republicanismo cívico liberal», R. Dworkin, Sovereign Virtue, Harvard U. P., Cambridge, Mass, 2000, pp. 211 ss.

${ }^{15}$ En parte de este epígrafe recupero algunos pasos de F. Ovejero, «Mercado y democracia», en A. Arteta, E. García, R. Máiz (eds.), Teoría política, Madrid, Alianza, 2003. 
libremente aceptada, obliga a sus protagonistas y sólo a sus protagonistas. La opresión empieza cuando las decisiones de «otros» recaen sobre mí y mi libertad aumenta cuando aumentan los ámbitos de mi vida que están excluidos de esas decisiones. El mercado, en una visión idealizada, es una institución que encarnaría el ideal liberal. El mercado «coordina las actividades individuales de personas egoístas sin necesidad de directrices políticas detalladas» ${ }^{16}$. Por contra, la democracia no tiene fácil encaje en el núcleo liberal. La democracia, en distinto grado, permite la participación de todos en la toma de decisiones que afectan a todos. Un riesgo para la libertad negativa. Por dos razones: porque las decisiones adoptadas por la mayoría alcanzan a la vida de cada uno y porque la democracia reclama una participación, siquiera elemental, en la gestión de la vida colectiva. En realidad, la política misma es un problema para el liberalismo. Por definición, las leyes no excluyen a nadie de su consumo, son bienes públicos. Nos guste o no, recaen sobre nosotros.

La tensión entre democracia y libertad no es independiente de las motivaciones de los ciudadanos. Las relaciones de intercambio, en principio, no exigen generosidad: cada cual se lleva lo que quiere; si no, no hay intercambio. Por definición, es un óptimo de Pareto. En la democracia las cosas son diferentes: todos deciden la ley a la que yo me someto. La tensión puede mitigarse si los otros al votar tienen en cuenta mi propia libertad, si los ciudadanos se comprometen a asegurar la libertad de todos. Ahora bien, si buscan su propio beneficio, si son calculadores egoístas que únicamente se preocupan de ellos mismos, pueden, por ejemplo, decidir, sin mi acuerdo, que yo «trabaje» para ellos. Incluso pueden decidir que no disponga de derechos.

El liberalismo adopta la hipótesis antropológica más austera: el homo oeconomicus. No excluye las disposiciones cívicas, que las personas participen en la política o que ayuden a los necesitados, pero, en todo caso, le parece mal que se exija la participación o que se obligue a pagar impuestos. El diseño de las instituciones se hace asumiendo la ausencia de virtud. Con esos mimbres el principio de libertad negativa y la ausencia de virtud es un problema la democracia. En realidad la única solución para preservar los derechos - la libertad - consiste en rebajar la democracia, limitar su alcance, diseñar una democracia que «funcione» sin disposiciones públicas en los ciudadanos y que no se entrometa en sus vidas ${ }^{17}$. En buena medida ésa es la

${ }_{16}$ J. Buchanan, «Vuelto a nacer economista», W. Breit y R. Spencer (eds.), Mi vida como economista, Madrid, Celeste, 1993, p. 220.

17 Desde el punto de vista de su fundamentacion, la democracia liberal tiene que compatibilizar su función como institución política (resolver los asuntos públicos), su fundamentación liberal (preservar la libertad negativa), su principio de legitimidad democrática (la voluntad expresada en votos) y su pesimismo antropológico: la presunción de ausencia de virtud cívica. De acuerdo con su inspiración liberal el mecanismo está diseñado para funcionar sin virtud o con el mínimo de virtud. En ese sentido, guarda parecidos no irrelevantes con el mercado ( $\mathrm{y}$ también diferencias impor- 
solución adoptada por las democracias constitucionales. De diversas formas, éstas compatibilizan la toma decisiones colectivas con el principio de maximización de la libertad negativa y la ausencia de virtud ${ }^{18}$. En primer lugar, la existencia de un cuerpo de representantes que realiza profesionalmente las tareas políticas minimiza las exigencias de virtud ciudadana. Los ciudadanos se limitan a elegir unos representantes encargados de realizar las tareas públicas. En segundo lugar, el Estado, asume un principio de neutralidad acerca de las concepciones de bien de los ciudadanos. En tercer lugar, existe un amplio catálogo de derechos recogidos constitucionalmente, que se imponen como cotos vedados a la voluntad de las mayorías democráticas. Finalmente, la garantía de los derechos es externa a la ciudadanía, su reconocimiento y su garantía no dependen de las decisiones o el compromiso de los ciudadanos, sino que vienen fijados constitucionalmente y asegurados por tribunales constitucionales, por una institución contramayoritaria no sometida a control democrático y, de facto, al generar doctrina constitucional, con potencial legislativo.

Con la honestidad intelectual que le caracterizaba, Berlin reconoció que la democracia y el liberalismo no se llevaban bien. Incluso que «pueden chocar entre sí de manera irreconciliable» ${ }^{19}$. No está sólo en esa reflexión que, con el tiempo, ha ido ganando perfil ${ }^{20}$. Como se acaba de ver, hay razones poderosas para que esa relación sea conflictiva. La duda es si están justificados los temores de Rawls: si las instituciones por sí mismas, sin virtud, pueden asegurar la libertad; si los derechos y la libertad, están a salvo; si, en suma, hay una alternativa a la «solución» liberal de atrincherar los derechos. El republicanismo presenta su propia solución, al menos en alguna de sus versiones.

\section{Modelos de virtud cívica}

Para ver cómo esto es así, empezaré por distinguir entre cuatro modelos distintos de relación entre la participación y la democracia. Deslindaré dos planos diferentes, presentes en la discusión sobre la naturaleza de la virtud en la

tantes). Con más detalle en F. Ovejero, «Mercado y democracia», op. cit. Volveré sobre esta idea de democracia más abajo.

18 Sieyès expresará bien claro esa «libertad» que aumenta cuando disminuye la participación: «Es indiscutible que hacerse representar en el mayor número de cosas posibles es acrecentar la propia libertad», «Opinión de Sieyès sobre varios artículos de los títulos IV y V del proyecto de constitución», 25 julio de 1795, Escritos políticos de Sieyès (Ed. de D. Pantoja), México, FCE, 1993, p. 243.

19 «Es mejor enfrentarse a este hecho intelectualmente incómodo que ignorarlo», I. Berlin Cuatro ensayos sobre la libertad, Madrid, Alianza, 1988, p. 59.

${ }^{20}$ De distinta forma, con distintas herramientas: F. Hayek, The Constitution of Liberty, Londres, Roudledge, 1960; W. Riker, Liberalism against Populism, San Francisco, Freeman, 1982. 
participación y que, sin embargo, no se acaban de hacer explícitos. El primero, normativo, distingue entre la justificación de la participación como un medio y la justificación de la participación como un valor en sí mismo. En el primer caso se sostiene, por ejemplo, que la participación es buena para el funcionamiento de la democracia ${ }^{21}$. En el segundo, se diría que la participación es buena para los que participan: para alguna cualidad de los ciudadanos, por ejemplo, su desarrollo personal (para la «transformación y la educación de los participantes») ${ }^{22}$. La distinción no se corresponde con la clásica $-\mathrm{y}$, a mi parecer, discutible - contraposición entre justificaciones consecuencialistas y deontológicas. Las dos estrategias, en realidad, apelan a las consecuencias de la participación. Sólo que en un caso recaen en el propio individuo y en el otro no ${ }^{23}$.

Por supuesto, no es imposible que quienes defienden la participación «como un fin en sí mismo», crean también que tiene buenas consecuencias «instrumentales» que resulte beneficiosa para la democracia. De hecho, como se verá más adelante, hay razones poderosas para pensar que la mejor calidad de las decisiones se asegura con una mayor participación, con más virtud cívica. En todo caso, lo que importa subrayar es que quienes destacan «el valor por sí mismo» de la participación pueden, sin contradicción, prescindir de cualquier consideración respecto a la bondad de las decisiones adoptadas. Podrían pensar, por ejemplo, que la participación mejora la vida de los ciudadanos, pero que no por ello el aumento en el número de los participantes no hace más atinada la decisión adoptada, que da lo mismo que la decisión la tome uno o un millón ${ }^{24}$. Incluso podrían creer que una ciudadanía activa es inconveniente para la calidad de las decisiones, aunque resulte bueno para los ciudadanos ${ }^{25}$.

21 Después precisaré la relación que, desde el republicanismo, se da entre la participación y la calidad de la democracia: la libertad republicana exige la ausencia de dominación; ésta, se asegura con la ley justa, que, a su vez, es resultado de una deliberación que mejora con la participación. En todo caso, eso no excluye otra secuencia causal.

22 J. Elster, «The market and the forum», J. Elster y A. Hylland (eds.), Foundations of Social Choice Theory, Cambridge, Cambridge U. P., 1986, p. 103.

${ }^{23}$ En otro sentido se podría hablar de dos objetivos distintos a maximizar: las decisiones (la democracia); los ciudadanos (alguna cualidad suya). Las dos son consecuencialistas. Quizá un ejemplo sirva: se puede correr como un fin en sí mismo (para mantenerse en forma) y se puede correr para algo ulterior (llevar una carta con rapidez). El contrafáctico ayuda: si el objetivo es en sí mismo correr, se puede materializar de diversa manera (jugar a fútbol, a tenis, etc.).

${ }^{24}$ Frente a esto, se ha querido demostrar que una decisión es más probablemente acertada cuantos más participen en ella. Para ello, amparándose en las propiedades matemáticas de la adición de probabilidades, se ha hecho uso del teorema de Condorcet, que muestra que, bajo ciertas condiciones (fundamentalmente, que la probabilidad promedio de que los decisores tomen la decisión correcta sea superior a 0,5 ), el aumento de número de decisores - y/o de su competencia epistémica media - aumenta la probabilidad de tomar decisiones correctas. Por supuesto, no faltan las críticas (no al teorema, sino a su uso, a sus condiciones de aplicación).

${ }^{25}$ La primera parte de esa afirmacion, en distintas versiones y calidades, la sostendrán, por ejemplo, los federalistas, The Federalist Papers, núm. 10, Nueva York, Mentor Book, 1961, o la 
El otro eje distinguiría entre presencia y ausencia de virtud cívica ${ }^{26}$. La participación puede resultar benéfica para el individuo en algún sentido, pero no por ello ha de tener éste una natural disposición a participar. Al cabo, con un ejemplo, a contrario sensu, tenemos una natural disposición hacia lo dulce - y a otras cosas peores - que, en nuestras sociedades, no resulta provechosa en ningún sentido razonable. En este caso, la contraposición se deja ilustrar de modo más inmediato: el homo oeconomicus carece de tal disposición y el ciudadano virtuoso la tiene.

A partir de ahí cabría reconocer cuatro modelos. El primero (liberal puro) no considera importante por sí misma la participación y cree que los ciudadanos carecen de vocación participativa. La preservación de la salud de la república ha de quedar, si es posible, en manos de las leyes, de una constitución fuerte o de sistemas de contrapesos, defensivos y mutuamente desconfiados. La participación tiene un papel (discretamente) instrumental: penalizar a los gobernantes ineficientes. Sería el caso de un liberalismo que no confía - bien por su pesimismo acerca de la disposición ciudadana, bien por entenderla como una fuente de problemas para la «racionalidad» del debate democrático - en la participación; hace de la protección frente a las intromisiones «públicas» el asunto fundamental y diseña las instituciones de tal modo que pueda prescindir de ella. Buena parte de los problemas de las modernas democracias se corresponderían con este modelo. Unos problemas que no resultan fáciles de solucionar desde los supuestos antropológicos liberales. Como se acaba de ver en la sección anterior, cuando se asume que los ciudadanos son egoístas, el único modo de proteger a los ciudadanos - su libertad negativa que se entiende como autonomía - es limitar la participación, atrincherar los derechos frente a las intromisiones de las voluntades mayoritarias. Pero, claro, entonces la democracia - como reconoce ese honesto liberal que es Rawls- se pone en peligro ${ }^{27}$.

Comisión trilateral, Michel Crozier, Samuel P. Huntington y Joji Watanuki, The Crisis of Democracy: Report on the Governability of Democracies to the Trilateral Commission, New York University Press, 1975.

${ }^{26}$ La distinción entre republicanismo a secas y republicanismo como humanismo cívico se apoya muchas veces en ese criterio. Así, por ejemplo, M. Zuckert, quien hace una apreciable presentación de «la síntesis republicana» y distingue entre el caso en el que el republicanismo emerge como un medio hacia la meta de la libertad y otro en el que es la expresión natural o directa de la naturaleza esencial del hombre como animal político. Por lo demás, Zuckert es bastante crítico con una síntesis «que no es lo bastante monolítica para merecer la calificacion de "síntesis", The Natural Rights Republic: Studies in the Foundation of American Political Tradition, Notre Dame, University of Notre Dame Press, 1996, p. 151.

27 El republicanismo, por lo general, se ha puesto del lado de la democracia e, incluso, la siempre complicada garantía normativa de los derechos, la ha realizado apelando a la democracia, tanto en su fundamentación como en su preservación. Los derechos no son aquello que está más allá del demos, sino aquello que el demos, que los considera justos, asegura colectivamente, precisamente porque los considera justos. Para estos puntos de vista: J. Waldron, Liberal Rights, Cambridge, Cambridge U. P., 1993. Volveré más adelante sobre esta idea. 
El segundo modelo (republicanismo comunitario) entiende la importancia instrumental de la participación para la salud de la república, pero cree que no existe disposición. Es el caso, entre los republicanos contemporáneos, de Sandel, quien no duda en mencionar una serie de virtudes (honestidad, fidelidad marital, sencillez, frugalidad, autocontrol, moderación, respeto, pasión por la vida pública, disciplina, respeto por la autoridad, patriotismo, piedad religiosa) que deberían ser alentadas públicamente ${ }^{28}$. La virtud, que no se da, debe ser impuesta ${ }^{29}$. Habría que «obligar al ciudadano a ser libre» (Rousseau, Contrato social, I,VI) ${ }^{30}$. Es así como muchos interpretaran el impactante lema de Robespierre: «la vertu, sans laquelle la terreur est funeste. la terreur, sans laquelle la vertu est impuissante» ${ }^{31}$. No faltan los ejemplos de actividades que cumplen la doble condición de «buenas por sí mismas» y ausencia de disposición. El aprendizaje de una disciplina (la música, las matemáticas) no se demanda espontáneamente. El inicio de la actividad es penoso, no retributivo. Para demandarla, para disfrutarla, se necesita aquello que sólo se obtiene una vez se ha consumado el aprendizaje: sólo quien ha estudiado matemáticas aprecia las matemáticas. Y no siempre. Por eso la enseñanza tiene que ser obligatoria. Pero lo que vale para la escuela quizá no valga para la virtud cívica, una mercancía delicada. $\mathrm{Y}$ es que la «actuación correcta por las razones correctas» requiere de la autonomía, precisamente lo que se «suspende» cuando se impone, cuando el sujeto responde a «premios y castigos», a incentivos, realiza «acciones correctas por las razones correctas» ${ }^{32}$. La objeción de Rawls parece afectar, sobre todo, a este caso.

${ }_{28}$ M. Sandel, Democracy's Discontent, Cambridge, Harvard U. P., 1996. Sandel no puede ser despachado sin más con el expediente de «comunitarista». Sus esfuerzos por no confundir el republicanismo con el liberalismo, que le llevan a destacar las líneas de demarcación (neutralidad del Estado, ausencia de virtud) con el liberalismo igualitario (Kymlicka) y con el republicanismo liberal (Pettit), han contribuido decisivamente a centrar el debate, cfr. la polémica con estos autores, entre otros, en A. Allen y M. Regan Jr. (eds.), Debating Democracy Discontent, Oxford, Oxford U. P., 1998.

${ }^{29} \mathrm{El}$ tradicional énfasis republicano en la educación encontraría aquí su amarre, cfr. «Symposium on Citizenship, Democracy and Education», Ethics, núm. 105, 1995.

30 Es obligado recordar que la interpretación «totalitaria» de este aserto de Rousseau es más que discutible. Sobre ello, cfr. S. Affeldt, «The Force of Freedom. Rousseau on Forcing to Be Free», Political Theory, 27, 3, 1999, pp. 299-333.

${ }^{31}$ «Rapport sur les principes de morale qui doivent guider la Convention dans l'administration intérieure de la République», 5 febrero de 1794, Oeuvres complètes de Maximilien Robespierre, (ed. E. Déprez et alt.), Paris, PUF, 1910-1967, vol. X, p. 357. Sobre las relaciones entre virtud y terror en Robespierre, cfr. D. Jordan «The Robespierre problem», en C. Haydon y W. Doyle (eds.), Robespierre, Cambridge, Cambridge U. P., 1999, pp. 29 ss. (de ahí tomo la referencia de la cita).

32 Entiendo aquí «autonomía» en el mismo sentido que Rawls al describir la idea kantiana: «una persona está actuando autónomamente cuando los principios de su acción son escogidos por él como la expresión más adecuada a su naturaleza de individuo racional, libre e igual», A Theory of Justice, Oxford, Oxford U. P., 1999, p. 252. Aquí se reconocen las piezas básicas: racionalidad, disposición natural, sometimiento a la ley libre y racionalmente elegida. Una versión menos libe- 
En el tercer modelo (republicanismo autorrealizador) la participación tiene valor en sí misma y existe una disposición natural. La democracia se justificaría en la medida que permite la realización de la participación, de la virtud, si se quiere. Se corresponde con una versión antropológicamente idealizada - la de Hannah Arendt y, más matizada, en Carol Patterman- de la democracia ateniense. Es una argumentación tradicionalmente republicana ${ }^{33}$ (aunque también está presente en Stuart Mill). Asume la existencia de disposiciones virtuosas, de unas capacidades humanas orientadas hacia el ejercicio práctico, racional, de «ser dueños de la propia vida» que, aun si latentes, como la capacidad lingüística, encontrarían su normal realización en los escenarios públicos ${ }^{34}$. Se sostiene en cuatro premisas: $a$ ) una parte importante de los talentos humanos sólo se pueden ejercer y desarrollar en colaboración; $b$ ) los seres humanos tenemos una natural disposición a ejercer tales capacidades; $c$ ) entre tales capacidades se encuentra la disposición al autogobierno, a querer regirse por sí mismos, a ser dueños de sus vidas o, mejor, a actuar de acuerdo con las razones que uno mismo suscribe ${ }^{35}$; d) la democracia participativa permite el autogobierno, el ejercicio de esas capacidades. A partir de esas premisas se justificaría la democracia republicana en tanto permitiría ejercer tales talentos. Cuando esa disposición se frustra, se atenta contra aspectos constitutivos de los seres humanos, contra lo que hay de más humano en cada uno de nosotros: la autonomía, la dignidad, la autorrealización.

Este republicanismo ha sido objeto de críticas que han destacado que la autorrealización, por su propia naturaleza, no puede servir para justificar la democracia ${ }^{36}$. Toda justificación, más o menos explícitamente, toma la forma de: «Y (la autorrealización, en este caso) es deseable»; «hacer X (lo fun-

ral, más clásica, participaría de tres premisas: a) el bien de cada persona consiste en desarrollar su naturaleza; el cual $b$ ) supone un importante elemento de actuar virtuosamente hacia los otros; c) tiene razones normativas para hacerlo, T. Hurka, «The Three faces of Flourishing», E. F. Paul, F. Miller Jr., J. Paul (eds.), Human Flourishing, Cambridge, Cambridge U. P., 1999. $84,1$.

${ }_{33}$ V. Brown, «Self-government. The Master Trope of Republican Liberty», The Monist, 2001 ,

34 La argumentación remite a la tópicamente llamada «libertad de los antiguos» — para otros, «libertad positiva»- entendida como el «control y dirección de la propia vida» y, en particular, con «la libertad de participar en las decisiones sociales que afectan a la propia vida». Conviene advertir que bajo la misma etiqueta de «libertad positiva» se cobijan tres ideas diferentes: libertad «real» entendida como poder o capacidad para hacer algo, opuesta a la libertad formal, a la simple ausencia de interferencias; libertad como «autonomía» entendida como autogobierno, opuesta a la libertad para hacer lo que se desea; libertad para participar en las actividades públicas, opuesta a la libertad «frente» a lo público.

35 También por detrás de «autogobierno» se dan diferentes ideas: gobierno de todos o gobierno del bien común; autonomía, autodeterminación, o, incluso, autorrealización y acceso a los medios de autorrealización. Y cada una de esas ideas admite formulaciones diversas; así, la autodeterminación en unos casos es determinarse uno mismo de acuerdo con una naturaleza esencial y en otros determinarse uno mismo de acuerdo con las leyes o planes que uno legisla o escoge para uno mismo.

36 J. Elster, «The market and the forum», art. cit. 
damentado: la participación) asegura la consecución de Y»; por tanto: «Debe hacerse X». Ahora bien, dirán los críticos, sucede que la autorrealización «no se puede perseguir directamente»: sólo cuando se realiza algo y ese algo se realiza exitosamente, se experimenta la autorrealización. La autorrealización es un «efecto lateral» de - la realización de - otra acción y, por ello mismo, por no poder perseguirse directamente, el empeño de «autorrealizarse» estaría llamado al fracaso. Intentar autorrealizarse sería como intentar ser espontáneo, esforzarse por dormirse o por olvidar a alguien. Así las cosas, siguen los críticos, no cabría «buscar» la autorrealización, planificar su obtención, ni, por ende, justificar en ella la democracia.

No estoy seguro de que la objeción, tal cual, resulte tan poderosa como parece. No hay que confundir el punto de vista de la primera persona - la que se «realiza»- con el punto de vista de la tercera persona, la que decide el diseño de las instituciones que permiten la autorrealización y que se justifican por ella. Un Gobierno que, por ejemplo, considerase que las actividades culturales maximizan la autorrealización de las gentes, puede potenciarlas y, de ese modo, favorecer la autorrealización. Su punto de vista no es el de los agentes que se realizan: una cosa son las actividades de los individuos -que les permiten autorrealizarse - y otra la política que favorece tales actividades. Los ciudadanos no pueden perseguir, sin más, «realizarse», pero nada impide llevar a cabo acciones políticas para procurar la realización de los ciudadanos ${ }^{37}$. Estas últimas sí que pueden estar abiertas a planificación. Desde otro punto de vista eso equivale a reconocer que, normativamente, no hay ningún problema en apelar a los resultados laterales de $\mathrm{X}$ (buena salud) para justificar $X$ (correr). Una cosa es que esté condenada al fracaso la acción que persigue directamente lo que es un subproducto y otra el que esa acción se justifique por sus subproductos ${ }^{38}$.

Sin embargo, la objeción anterior puede reconstruirse de modo más preciso a partir del reconocimiento de que la autorrealización a través del auto-

\footnotetext{
${ }^{37}$ En ese sentido no resultan pertinentes las críticas de J. Elster a H. Arendt, «The Market and the forum», art. cit. cfr. F. Ovejero, «Teorías de la democracia...», particularmente los textos de las notas 50 y 56.

38 Incluso una acción podría fracasar en su objetivo y justificarse por sus subproductos (porque, por ejemplo, contribuye a forjar el carácter, el proceso de maduración, la responsabilidad). Aun si la acción o el proceso A no permitiera obtener máximamente $\mathrm{x}$ (conjetura empírica), yo podría defender $\mathrm{A}$ porque la búsqueda de $\mathrm{x}$ a través de $\mathrm{A}-\mathrm{y}$ sólo a través de $\mathrm{A}$ - permite obtener $\mathrm{z}$.

Por lo demás, como se dice en el texto, no está nada claro que conocer la condición de subproducto de algo nos impida perseguirlo instrumentalmente, una vez reconocemos esa condición de subproducto: yo puedo buscarme problemas más importantes para olvidarme de otro que me obsesiona (y que no puedo esforzarme por olvidar «voluntariamente»). Cfr. las críticas a la teoría de los subproductos de Elster en sus juicios sobre la democracia republicana de Arendt: J. Chan, D. Miller «Elster on Self-realization in Politics: A Critical Note», Ethics, 1991, p. 102. En ese trabajo los autores reconocen diversos grados de imposibilidad para perseguir y obtener los subproductos políticos. Asimismo sobre lo razonable de los objetivos inalcanzables, N. Rescher, Ethical Idealism, Berkeley, University of California Press, 1987.
} 
gobierno presenta unas particularidades que dificultan su planificación. El problema radica en que, en este caso, se trata de la realización de una tarea colectiva - de decidir sobre la propia vida - y eso complica el éxito de la tarea. Repárese en que las premisas anteriores no aseguran que el individuo se autogobierne, y, si eso es así, no hay «realización exitosa». Se requiere, además de que se satisfagan tales premisas, que las preferencias suyas coincidan con las agregadas, con la voluntad general. Yo puedo querer A, pero si los demás quieren $\mathrm{B}$, no sentiré que me autogobierno ${ }^{39}$. La buena naturale$\mathrm{za}$, mi compromiso con el interés general, ayuda pero no resuelve. No todos tenemos por qué estar de acuerdo acerca de en qué consiste el interés general, e incluso puede que discrepemos acerca de cómo determinarlo ${ }^{40}$. Cierto es que la deliberación, en principio, proporciona un procedimiento: nos compromete con criterios de imparcialidad que permiten dilucidar entre las propuestas. Pero tampoco resulta concluyente. Incluso puede ampliar el campo de las discrepancias. En la discusión, pueden aparecer nuevas alternativas que «no se nos habían ocurrido» ${ }^{41}$. Así las cosas, la decisión democrática no asegurará la realización exitosa del objetivo (el autogobierno) y, sin ésta, no hay autorrealización ${ }^{42}$.

El último modelo, en donde la participación tiene valor instrumental pero existe disposición a participar, justifica -en el sentido que se verá más abajo- la democracia por su relación con las leyes justas, que aseguran la libertad ${ }^{43}$. En este caso, dada la existencia de la disposición, no se da el pro-

${ }^{39}$ Cabría pensar en dos réplicas a esta objeción: a) que para la autorrealización basta el debate, con independencia de su resultado (lo importante sería cocinar o escribir, no la calidad del producto); $b$ ) que la deliberación puede llevar a modificar las preferencias, a la luz de las mejores razones, de tal modo que, al fin, se ajusten a la voluntad general. La primera réplica resulta difícilmente aceptable: cualquier actividad, por serlo, se convertiría en autorrealizadora con independencia de si tiene un buen resultado (y la autorrealización es inseparable de su reverso). La segunda resulta más atendible, pero peca de irrealista.

${ }^{40}$ El mismo Rousseau detectaba la tensión entre «la voluntad de todos» y la «voluntad general», Contrato social, II, III. Su «solución» la ha reconstruido J. Neidleman: «el salto entre la voluntad popular y la voluntad racional es la ciudadanía», The General Will is Citizenship, Rowman, Littlefield, 2001, p. 10.

${ }^{41}$ De hecho, la deliberación puede generar nuevas paradojas de agregación como resultado de ampliar las divergencias. Imaginemos a tres ciudadanos (A, B, C) que, después de deliberar si $\mathrm{X}$ es un problema lo bastante importante y de si $Y$ (una medida costosa) es eficaz para paliar $X$, han de tomar una decisión. Naturalmente para estar a favor de la propuesta hay que creer que $\mathrm{X}$ es importante y que $\mathrm{Y}$ sirve. Dadas esas circunstancias, podría darse que una mayoría crea que $\mathrm{X}$ es importante, otra mayoría creer que $\mathrm{Y}$ sirve y, sin embargo, la mayoría estar en contra de adoptar la medida. Sería el caso, por ejemplo, si A piensa que $\mathrm{X}$ es un problema real, pero que $\mathrm{Y}$ no sirve, $\mathrm{B}$ cree que $\mathrm{X}$ no es importante, aunque esté convencido de que $Y$ es eficaz y que $C$ está de acuerdo en la importancia de X y en la eficacia de Y. Christian List and Philip Pettit, «The aggregation of reason» (mimeo). J. Dryzek, Ch. List, «Social Choice and Deliberative Democracy: A reconciliation» (mimeo).

${ }_{42}$ Es autorrealización política, autogobierno, lo que impide la asimilación a la política cultural (el punto de vista de a-intervención desde la tercera persona).

${ }^{43}$ Se podría pensar que describe los procesos revolucionarios (o constituyentes, en la terminología de B. Ackerman, We the People, Cambridge, Harvard U. P., 1991). 
blema de acción colectiva, el de «Rawls y la virtud». Queda ejemplificado por aquellas situaciones en donde las acciones de los individuos, inspiradas en sus propios objetivos, caminan en la misma dirección que resultados interesantes desde el punto de vista colectivo, previstos o no. Por ejemplo, el mercado, o, más en general, cualquier otro caso de mano invisible: los agentes egoístas procuran - está en su naturaleza - buscar su beneficio y esa disposición tiene buenas consecuencias para la coordinación social (eficiencia, etc.). En el caso de la república, por supuesto, las disposiciones son otras. Como en el republicanismo autorrealizador, el buen ser humano, el completo, no puede dejar de ser un buen ciudadano porque la disposición a participar forma parte de su propia humanidad ${ }^{44}$. Realiza y reconoce su excelencia humana en la actividad pública y procura ejecutar con destreza esa tarea. En ese sentido, la libertad de la república vendría a ser una suerte de subproducto de la naturaleza humana, esencialmente virtuosa. Y, desde luego, no se ve por ninguna parte la sombra de violencia a la autonomía.

Ello no quiere decir que la democracia se justifique porque contribuye a la autorrealización. Ni tampoco que el ciudadano participe en la actividad pública para - con el objetivo de - autorrealizarse. La democracia se justifica porque favorece las decisiones más justas, las leyes que aseguran la libertad de los ciudadanos. El ciudadano participa para decidir, del mejor modo, cómo vivir colectivamente. Con ello, dada su naturaleza, ejerce parte del reto de vivir en la actividad pública y, de ese modo, se asegura la posibilidad de gobernar sus destinos. No busca, con ello, realizarse. Lo que busca, y lo que justifica la democracia, son las buenas leyes. Ése es el valor -instrumental- de la democracia. Al decidir cómo vivir, al realizar algo exitosamente, tiene la posibilidad - sólo la posibilidad - de experimentar la política como realización. Pero la autorrealización no constituye el fundamento o la justificación de la democracia: aunque se autorrealicen en la política, los ciudadanos no deliberan para autorrealizarse, sino para decidir correctamente. La democracia (deliberativa, participativa) no se justifica por la autorrealización, sino porque constituye el mejor procedimiento para decidir sobre la vida compartida. La (experiencia de la) realización de algo (la decisión política, en este caso) y que la realización esté justificada (que ese algo tenga sentido) son condiciones causales - producen el efecto lateral- de la autorrealización ${ }^{45}$. Pero condiciones necesarias, no suficientes.

${ }^{44}$ Punto de vista clásicamente atribuido a Aristóteles. Hay un inacabado debate acerca del papel que para Aristóteles cumple la participación política en la persecución del telos humano, la eudamonia. Para una mirada crítica del debate, cfr. T. Duvall y P. Dotson, «Political Participation and Eudaimonia in Aristotle's Politics», History of Political Thought, XIX, núm. 1, 1998.

${ }_{45} \mathrm{Sin}$ olvidar que la autorrealización (politica) resulta posible porque se da la deliberacion, la posibilidad de modificar las preferencias a la luz de las mejores razones, la autonomía, al fin. Cuando el resultado está determinado de antemano, el convencimiento, la elección de retos y la deliberación pierden todo sentido. Por eso resulta la realización ciudadana desde el horizonte de una idea sustantiva de bien comunitarista: El ciudadano enfrenta un reto elegido: como reto, exige 
En ese sentido, como se verá en la sección siguiente - y como correctamente destacaba Rawls- la virtud resulta instrumental para la democracia. Incluso más, la propia democracia lo es para el republicanismo: asegura la libertad, el valor más importante.

Llegados aquí, obviamente, el problema (si no se quiere «resolver» tautológicamente los problemas, asumiendo, por petición de principio, que existe la buena naturaleza política que nos interesa) es determinar si existen tales disposiciones y, en el caso de que sea así, cuáles son las mejores condiciones institucionales y sociales para que puedan ejercitarse. El segundo aspecto nos remite inmediatamente al paisaje de fondo, económico y social, de la buena sociedad republicana, sobre lo cual se pueden decir pocas cosas bien firmes. Con matizada firmeza sí que se puede decir que si ése es el mercado, tendrá que ser embridado en sus consecuencias más desigualitarias: la desigualdad - que, además de la contraposición de intereses, conlleva el alejamiento de las experiencias, los modos de vida, los problemas- complica la aparición de los compromisos de ciudadanía. Y no sólo en ellas: el mercado refuerza unas disposiciones cognitivas (egoísmo, evaluación contable de las relaciones humanas, hedonismo) poco propicias al cultivo de las normas (de confianza, lealtad, respeto, etc.): los elementales vínculos de reciprocidad o las emociones de justicia resultan socavados cuando cada ciudadano no echa otras cuentas que las de su interés inmediato ${ }^{46}$

El segundo aspecto es el que le preocupa a Rawls y, en su pesimismo antropológico, le lleva a criticar a un republicanismo que no puede dejar de ser comunitario, de intervenir en nombre de una naturaleza humana cuya excelencia hay que realizar, incluso a su pesar. Finalmente, la confirmación de la existencia de disposiciones es, sobre todo, un asunto empírico. ¿Es el caso que la naturaleza humana tiene vocación pública? Un problema, por

su correcta realización; como elegido, se experimenta como realización: no hay realización si no hay autonomía, si no se eligen libremente los retos. Sobre estos aspectos en relación con la democracia cfr. F. Ovejero, «Teorías de la democracia y fundamentaciones de la democracia», art. cit. especialmente la nota 67

${ }^{46}$ En ese sentido - y sólo en éste-resulta realista la teoría de la elección racional en sus modelos políticos sobre la democracia, cuando presume que el mismo individuo que el mercado produce (el homo oeconomicus) se extiende a - y hay que tomar como punto de partida en- la democracia de competencia entre partidos. El efecto, además, se amplifica: las instituciones basadas en la desconfianza hacia - la posibilidad de- las disposiciones cívicas, penaliza y mata las disposiciones cívicas, cfr. B. Frey, «A Constitution for Knaves Crowds out Civic Virtues», The Economic Journal, núm. 107, 1997, pp. 1043-1053. Por otra parte, no faltan resultados empíricos sobre la existencia de la «mentalidad del mercado», sobre las estructuras cognitivas que refuerza el mercado: R. Lane, The Market Experience, Cambridge, Cambridge U. P., 1991. Sobre el choque con las normas, M. Radin, Contested Commodities, Cambridge, Harvard U. P., 1996; F. Ovejero, «Del mercado al instinto», Isegoría, núm. 18, 1998, pp. 181-203.

$\mathrm{Y}$ todo eso sin olvidar que el buen funcionamiento del mercado necesita de las normas que socava: A. Ben-ner y L. Putterman (eds.), Economics, Values and Organization, Cambridge, Cambridge U. P., 1998; W. Schultz, The Moral Condicions of Economic Eficiency, Cambridge, Cambridge U. P., 2001. 
cierto, que Rawls no ignora ${ }^{47}$. Es indiscutible que la especie humana tiene una notable disposición social, como se deja ver en la conformación - bajo presiones adaptativas - de muchas de sus estructuras cognitivas. Tenemos disposiciones cooperativas, y estamos dotados de un amplio surtido de repertorios emocionales que, coordinados, sirven de cimiento a nuestros sistemas normativos ${ }^{48}$. En todos esos casos, la capacidad está en nosotros, forma parte de nuestra herencia genética y, cabe conjeturar, opera a través de módulos, de estructuras neuronales especializadas en procesar ciertos inputs específicos, de un modo autónomo, automático e independiente ${ }^{49}$. Tales estructuras están programadas, al modo como sucede en el caso de lenguaje, aunque la activación y el desarrollo requiere de la propia socialidad (del mismo modo que el lenguaje o la dentición, también programados, requieren, respectivamente, de nutrientes y de una exposición a un entorno social).

Pero poco más. No hay —ni siquiera se sabe muy bien qué significaría eso- una «disposición natural» al republicanismo ${ }^{50}$. Las investigaciones empíricas invitan a dudar del homo oeconomicus, de una visión estrechamente egoísta de los seres humanos; incluso permiten reconocer la existencia en el seno de la especie humana - y en sus parientes próximos- de elementales principios de reciprocidad y hasta de sensibilidad para atender las necesidades básicas, pero, desde luego, no avalan nada parecido a la naturalidad del republicanismo, amén de que tales resultados, por más que intere-

${ }^{47}$ F. Ovejero, «Los motivos de la justicia», Claves de razón práctica, núm. 156, 2005.

48 Para una exposición sistemática de la relación entre procesos cognitivos y comportamiento moral: W. Rottschaefer, The Biology and Psychology of Moral Agency, Cambridge, Cambridge U. P., 1998. Un panorama de trabajos referidos a aspectos cognitivos, emocionales y (menos) morales en L. May, M. Friedman y A. Clark, Mind and Morals, The MIT Press, Cambridge, 1996. Sobre la ética de la virtud: P. Churchland, «Toward a Cognitive Neurobiology of the Moral Virtues», en J. Branquinho (ed.), The Foundations of Cognitive Science, Oxford, Oxford U. P., 2001. En relación con conceptos filosóficos que son condición de posibilidad de la «personalidad» ética: para la noción de identidad, agente moral, honestidad, O. Flanagan, Self-Expresions, Oxford U. P., 1996; para el papel de la imaginación en la ayuda para decidir en lo particular (y en oposición a la ética como «leyes universales dictadas por la razón»): M. Johnson, Moral Imagination. Implications of cognitive Science for Ethics, Chicago, Chicago U. P., 1993.

${ }^{49} \mathrm{La}$ hipótesis modular, desde una perspectiva evolutiva, en P. Carruthers y A. Chamberlain (eds.), Evolution and the Human Mind, Cambridge: Cambridge U. P., 2000.

${ }^{50}$ Hablarían en todo caso a favor de la no dominación en la medida que la dominación es incertidumbre. A lo sumo alcanzan a mostrar el «bienestar» asociado a la participación: R. Lane, «The Joyless Polity: Contributions of Democratic Processes to Ill-Being», S. Elkin y K. Soltan (eds.), Citizen Competence and Democratic Institutions, University Park, Penn State Press, 1999 Un repaso de la literatura sobre los resultados de psicología de la participación democrática: J. Sullivan y J. Transue, «The Psychological Underpinnings of Democracy», Annual Review of Psychology, núm. 50, 1999. De todos modos no me resisto a recordar que no faltan evidencias empíricas que avalan, por ejemplo, la relación entre felicidad - que algo captura de la eudaemonia, la noción clásica que está en la trastienda de la autorrealización- y democracia participativa (autogobierno): B. Frey y A. Slutzer, «Happiness, Economy and Institutions», The Economic Journal, núm. 110, octubre de 2000; R. Ryan y E. Deci, «On Happinesss and Human Potencials: A Review of Research on Hedonic and Eudaimonc Well-Being», Annual Review of Psychology, núm. 52, 2001. 
santes, están lejos de abandonar el territorio de los indicios ${ }^{51}$. En el que, por lo demás, tampoco podemos esperar demasiado ${ }^{52}$.

\section{Virtud, democracia y libertad}

En las líneas anteriores se asumía, con Rawls, una visión instrumental de la virtud. También con él, se relacionaba esa bondad instrumental de la virtud con la calidad de la democracia. En ese sentido, la virtud no aparece como un rasgo constitutivo del republicanismo. De hecho, la propia democracia resultaba instrumental respecto a la libertad, el valor más importante para la tradición republicana, el punto de llegada, normativo, que define al republicanismo y que Rawls no parece destacar en el paso que nos ocupa. En las páginas que restan quisiera precisar la naturaleza de esa relación instrumental entre virtud, ciudadanía y democracia y, a través de ésta, su vinculación con lo que constituye el núcleo del ideal republicano: la libertad.

El republicanismo no comparte la idea de libertad liberal, la libertad negativa, entendida como ausencia de intromisiones: «A es libre para hacer $X$ cuando nadie se interfiere en -impide, coarta- que haga $X \gg{ }^{53}$. Una idea demasiado exigente, que nos impediría calificar como plenamente libre a una sociedad que encarcela a los asesinos. Pero también una idea demasiado pobre, en tanto llevaría a considerar como libre al esclavo o al siervo cuyo amo, generoso, le deja hacer lo que quiere, por más que siempre esté en su mano la posibilidad de impedírselo. Frente a esta idea, los republicanos sostendrán que no toda interferencia está injustificada $\mathrm{y}$, sobre todo, que no

${ }^{51}$ F. Ovejero, La libertad inhóspita, Barcelona, Paidós, 2002, cap. I.

52 No deja de producir perplejidad la falta de cautelas con la que se relacionan imágenes obtenidas mediante PET (Tomografía por Emisión de Positrones) con comportamientos o disposiciones a comportamientos conceptualizados desde la teoría social o nuestro lenguaje común. Y es que no puede olvidarse el enorme - y acaso inevitable - salto conceptual que hay entre el plano de las instituciones y los procesos sociales en donde se desenvuelve la vida ciudadana y los marcos en donde se desarrollan los experimentos cognitivos habituales, por no referirse al salto entre esos mismos experimentos y los procesos cerebrales supuestamente implicados: una cosa es una revolución, otra una disposición mostrada en un grupo experimental y otra una red de conexiones sinápticas activadas. Por no referirse al «salto» entre módulos y genes. En cada uno de los pasos (genes, módulos, comportamientos, experimentos, escenarios sociales) se está presumiendo mucho y la evidencia disponible es limitada, cuando no puramente conjetural. De hecho, incluso entre partidarios de «darwinizar la cultura» hay agudas discrepancias, cf. las posiciones críticas - y las propias discrepancias entre ellos- de R. Boyd, P. Richerson y D. Sperber (entre otros) respecto a las propuestas más radicales (de Dennet), en R. Aunger (ed.), Darwinizing Culture. The status of memetics as a science, Oxford, Oxford U.P., 2000. Y el propio J. Fodor, responsable de la teoría modular, ha presentado una contundente crítica a la psicología evolutiva: The Mind Doesn't Work That Way, The MIT Press, Cambridge Mass., 2000.

53 Tampoco de la libertad positiva, entendida como autogobierno, como posibilidad efectiva de realizar los propios objetivos ( $\ll \mathrm{A}$ es libre para hacer $\mathrm{X}$ cuando, queriendo hacer $\mathrm{X}$, puede realmente hacer X»). 
toda violación de la libertad implica una interferencia. Una interferencia está justificada, y, por lo tanto, no viola la libertad, si es justa, si no es arbitraria ${ }^{54}$. Por eso no es menos libre una sociedad que encarcela a los criminales. A la vez, el esclavo con un amo generoso no deja de ser un esclavo. Su señor puede interferir cuando quiera en sus cursos de acción, aunque, de facto, no interfiera. Su señor está situado en una posición de dominación. Si quisiera podría interferir en sus acciones impunemente y a su arbitrio. Desde esta perspectiva un individuo es libre cuando no está sometido a interferencias arbitrarias 55 .

Para el republicanismo, la ley no es la frontera donde acaba la libertad, sino su condición necesaria, su garantía frente a los poderosos, la seguridad de que no estaremos sometidos intromisiones arbitrarias. El problema, claro es, consiste en delimitar el trazo entre las intromisiones arbitrarias y aquellas que no lo son. También la ley puede ser opresora, fuente de dominación arbitraria. ¿Cómo determinamos, entonces, la ley justa, la que es garantía de la libertad? En principio, también ahora la respuesta es inmediata: la democracia, la sociedad autogobernada que sólo se somete a la ley que ella misma se da. Desgraciadamente, desde Aristóteles, no ignoramos que la democracia también puede derivar en tiranía; la tiranía de los muchos sobre los pocos, pero tiranía al fin. ¿O no llamaríamos tiranía al acuerdo de diez para que otro, el más fuerte, trabajase para ellos?

Ahí es donde hace su aparición la deliberación democrática, que filtra los intereses según criterios de imparcialidad, atendiendo a la fuerza de los argumentos que las avalan. La argumentación pública obliga a mostrar que, en algún sentido, las tesis defendidas se corresponden con principios generalmente aceptables, de interés general. En ese caso, pierde todo sentido, «defenderse» frente a la mayoría: los intereses justos estarán recogidos en los intereses de todos. Por eso mismo, la idea republicana de los derechos, es bien distinta de la liberal. Los derechos no son barreras que se establecen

${ }^{54}$ La presente formulación recoge ideas apuntadas por Q. Skinner, «The idea of Negative Liberty», en R. Rorty, J. Schneewind y Q. Skinner (eds.), Philosophy in History, Cambridge, Cambridge University Press, 1984; desarrolladas por P. Pettit en distintos trabajos: «A Definition of Negative Liberty», Ratio, núm. 2, 1989; y «Freedom as Antipower», Ethics, núm. 106, 1996. Dos revisiones recientes del debate de años, robustas y sistemáticas, en $\mathrm{Q}$. Skinner, «A Third Concept of Liberty», Proceedings of the British Academy, núm. 117, 2003; P. Pettit, «Keeping Republican Freedom Simple», Political Theory, 30, 3, 2002.

55 P. Pettit, Republicanism, Oxford, Oxford U.P., 1997. La presentación más ordenada en P. Pettit, «Keeping Republican Freedom Simple. On a Difference with Quentin Skinner», Political Theory, vol. 30, núm. 3, 2002. Cit. para una historia de esa idea republicana: J.-F. Spitz, La liberté Politique, París, PUF, 1995. De todos modos, el excelente trabajo de Spitz exagera el trazo de contraponer una idea republicana de «libertad merced a la ley» frente a la libertad «presocial» (de Estado de naturaleza liberal»). Para matizar esa demarcación, cf. L. Jaume, La liberté et la loi. Les origines philosophiques du liberalisme, París, Fayard, 2000. Desde un vuelo histórico más dilatado en el tiempo, cf. el breve y excelente repaso de M. Barberis, Libertà, Roma, Il Mulino, 1999, especialmente el cap. III. 
alrededor de individuos autónomos», como entiende el liberalismo, sino, para decirlo con Marx, «derechos políticos que son únicamente ejercidos en comunidad con otros hombres». Y la participación es ahí fundamental: las demandas justas $y$, por ende, las interferencias arbitrarias se determinan a través de procesos de pública deliberación. La voluntad colectiva no puede verse como una forma de dominación, $y$, por tanto, no cabe pensar en «protegerse» frente a ella cuando está conformada a través de procesos de deliberación en donde actúan criterios de interés general entre individuos comprometidos con el interés general y que se comprometen con las decisiones que ellos mismos toman. Desde su perspectiva, si se toma en serio la idea de una comunidad democrática, es el propio acto de votación el que determina o altera los derechos dentro de la comunidad. No habría unos derechos anteriores a la propia comunidad política y, cuando ésta toma decisiones que se atienen a los intereses colectivos, no existe ningún vínculo necesario que equipare las decisiones de la mayoría a la opresión de las minorías ${ }^{56}$. Mal que bien, la democracia deliberativa asegura un razonable vínculo entre las decisiones y la justicia.

Ahora bien, cabría preguntarse: ¿dónde aparece aquí la virtud ciudadana? ¿Por qué no dejamos que deliberen sólo los mejores, los más virtuosos o, incluso más, que «delibere» privadamente el rey sabio que conoce lo más justo y decide por todos? ¿Por qué no confiar en una suerte de Hércules político capaz de ponderar todos los intereses y de librarse de toda influencia? Claro que para que eso sea posible es necesario, entre otras cosas, que podamos identificar a los excelentes ${ }^{57}$. Para muchos, las elecciones democráticas cumplían esa función. Los ciudadanos no virtuosos, egoístas e ignorantes, con sus elecciones estaban en condiciones de identificar a los mejores entre ellos ${ }^{58}$. Una vez elegidos, ellos deliberarían y determinarían las

56 La participación aparece entonces «como un derecho [...] que permite resolver a los ciudadanos los desacuerdos que tienen acerca de sus propios derechos», J. Waldron, «Participacion: The Rights of Rights», en Law and Disagreement, Oxford, Oxford U.P., 1999. La cita de Marx es del propio Waldron, p. 232, y procede de La Cuestión Judía. Por lo demás, esa herencia republicana de Marx ha sido cuidadamente explorada por A. Levine, The General Will: Rousseau, Marx Comunism, Cambridge, Cambridge U.P., 1993. Para notables y breves sistematizaciones del Marx demócrata radical: A. Gilbert, «Democracy and Individuality», E. F. Paul, F. Miller Jr., J. Paul y J, Ahrens (eds.), «Marxism and Liberalism», Londres, Basil Backwell, 1986; A. Gilbert, «Political Philosophy: Marx and Radical Democracy», T. Carver (ed.), The Cambridge Companion to Marx, Cambridge, Cambridge U.P., 1993.

57 Para esas otras cosas: J. Ferejhon, «Must preferences be respected in democracy?», en D. Copp, J. Hampton y J. Roemer (eds.), The Idea of Democracy, Cambridge, Cambridge U.P., 1993.

58 Con sus votos, los ciudadanos, mezquinos o ignorantes, identificarian «como gobernantes a los hombres de mayor sabiduría y discernimiento y mayor virtud para perseguir el bien común». A través de las elecciones democráticas, el poder político recaería en aquellos ciudadanos más excelentes, «que defienden a las gentes contra sus propios errores temporales y fantasías», «cuya sabiduría mejor pueda discernir los verdaderos intereses de la nación y cuyo patriotismo y amor a la justicia tenga menos probabilidades de ser sacrificado por consideraciones temporales de justicia», The Federalist Papers, núm. 10, op. cit., pp. 77 ss. 
leyes más justas. La virtud ciudadana, la participación, no aparece por ningún lado. Ésa era, en buena medida, la argumentación de los federalistas, Constant o Sieyès, entre muchos más ${ }^{59}$.

$\mathrm{Su}$ argumentación se apoyaba en dos premisas ${ }^{60}$. La primera relaciona la deliberación con las mejores decisiones, con las más justas. No parece una tesis discutible. La deliberación puede conducir a una conclusión incorrecta, pero, incluso para saber eso, para reconocer el error, se necesita deliberar. Hay que llegar a las mejores ideas, pero no hay otro modo de saber que hemos llegado que a través de la (pública) discusión que nos muestra que la idea está bien fundamentada, que ha superado las críticas y ha (con)vencido. No hay modo de saber que tenemos una tesis correcta que a través del examen de la calidad de su fundamentación, de las razones que la avalan.

La otra premisa es más dudosa: estamos en condiciones de identificar a los mejores, a los que habrían de deliberar. Es falso que los sistemas de representación puedan servir para reconocer a los más excelentes. Precisamente porque las cosas no son así es por lo que la participación y la virtud ciudadana resultan necesarias para la propia calidad de la deliberación: a través de una serie de mecanismos (recogida de información, corrección de sesgos, disminución de la discrecionalidad de los representantes), la participación propicia la identificación y la buena asignación de virtud y, con ello, mejora la calidad de la deliberación. La participación se justifica porque permite maximizar la bondad de la deliberación.

Los problemas de los sistemas de competencia electoral para identificar a los mejores derivan del particular tipo de relación que existe entre representantes y representados, en la que los primeros son elegidos por los segundos. Sucede que las condiciones de funcionamiento de los mercados políticos se alejan de las que rigen los dos únicos escenarios en donde es posible la selección de los más excelentes. El primero es el «modelo de tribunal de oposiciones», en el cual los que eligen son al menos tan competentes como los candidatos. Aquí opera el principio según el cual «para evaluar a los gestores se necesita conocer cómo se realiza la gestión». Este escenario está descartado por definición en el caso de los sistemas de representación que precisamente justifican la división del trabajo entre representantes y representados porque «no todos están en condiciones de evaluar la gestión» ${ }^{61}$. El otro escenario en el que las elecciones servirían para identificar a los mejo-

${ }^{59}$ Cf. R. Gargarella, Nos los representantes, Buenos Aires, Miño y Dávila, 1995; B. Manin, Los principios del Gobierno representativo, Madrid, Alianza, 1998.

${ }^{60}$ Con más detalle: F. Ovejero, «Modelos de democracia...», art. cit.

${ }_{61}$ Si todos pueden hacerlo, no se entiende para qué se necesitan las elecciones de representantes. Todos serían igualmente virtuosos y estarían en condiciones de gobernar. La división del trabajo no quedaría justificada en razones de eficiencia. ¿Por qué no utilizar, por ejemplo, un sistema rotatorio o de loterías para los cargos políticos que, después de todo es menos perverso (no se requiere el poder económico o el conspiratorio, siempre necesarios en el mercado electoral) y menos desintegrador (no es necesario competir agresivamente con los demás)? 
res, el modelo de «selector ciego», opera bajo el supuesto de que, en ciertas condiciones, «los ignorantes, aun sin pretenderlo, con sus acciones seleccionan a los mejores». El ejemplo clásico —además del algoritmo de la selección natural ${ }^{62}$ - es el mercado donde los consumidores con sus elecciones de consumo (el producto que les gusta) seleccionan al productor eficiente, aun si nada saben sobre las condiciones de producción. El consumidor puede ignorarlo todo acerca de cómo preparar una paella pero con sus elecciones sobre el producto acabado escoge al mejor cocinero y penaliza, sin pretenderlo, al malo. El problema es que las excepcionales circunstancias que se necesitan para que opere el sistema de «selector ciego» nunca se pueden dar en los mercados políticos. La idea básica es que los mismos mecanismos de representación política, que se justifican por su capacidad para identificar las disposiciones públicas, son los responsables de la penalización de esas disposiciones. Dadas las condiciones de funcionamiento de la «democracia» elitista, el votante no necesita estar interesado en la cosa pública: ignora la gestión y por lo mismo no puede evaluar las políticas. Por su parte, los representantes, que no son mandatarios, han de estar en condiciones de deliberar, de atender a las mejores razones, $y$, por tanto, han de poder modificar sus criterios. Esa situación les otorga una enorme discrecionalidad en la elección de los objetivos y en su realización. El político puede escoger entre hacer A o B y, además, puede describir a su gusto la accesibilidad de A y de B. En ese sentido, existe una situación de asimetría informativa entre unos y otros. Pues bien, en esas circunstancias, el comportamiento virtuoso del político es penalizado por el sistema de elecciones.

Las cosas funcionan del siguiente modo. Con desigualdad informativa, el ciudadano/consumidor no tiene modo de discriminar entre el político/productor sincero y el embaucador, el que tergiversa sus quehaceres y méritos para asegurarse el poder. El político siempre podrá exagerar las dificultades, escoger como tareas a realizar aquellas que ya vienen «dadas», describir la altura de las metas de tal modo que siempre las sobrepase, ofrecer metas de fácil realización, tergiversar la descripción de su esfuerzo, exagerar unos problemas y escamotear otros. El ciudadano no tiene modo de distinguir entre el político que se esfuerza honestamente por conseguir un resultado difícil y el que presenta como complicado lo que le viene dado; el votante lo único que sabe es que no sabe: para eso escoge a un político y para eso le retribuye. Por entre el que, cuando reclama su esfuerzo, exagera problemas falsos y el que señala dificultades reales; entre el que argumenta con datos fiables y el que manipula los presupuestos y las contabilidades. Por supuesto, por lo mismo, de nada le sirven lo que digan los otros políticos: no tiene modo de distinguir entre las críticas veraces y las interesadas. El ciudadano

62 D. Dennet, Darwin's Dangerous Idea: evolution and the meanings of life, Nueva York, Allen Lane, 1995 
sabe eso y sabe que no puede discriminar entre unos y otros. En esas condiciones, el político honesto que emplea su tiempo en estudiar los problemas e intentar resolverlos, se encuentra en peores condiciones que el que dedica su tiempo a asegurar - con favores, presencia en los medios de comunicación, acciones populistas - su reelección. Sistemáticamente el sistema político presenta un sesgo en contra del comportamiento virtuoso.

Lo anterior es, sobre todo, una crítica de la eficacia de los sistemas de competencia para identificar a los más excelentes. No equivale, en rigor, a una defensa de la participación. La argumentación, para completarse, necesita mostrar que la participación asegura una mejor «economía de la virtud» $y$, por ende, hace posible el buen funcionamiento de la deliberación. Buena parte de la reflexión reciente en democracia deliberativa ha estado orientada a ese objetivo ${ }^{63}$. Muy en general, se puede decir que las iniciativas participativas mejoran las circunstancias de la deliberación, al favorecer sus condiciones cognitivas y propiciar la identificación, el cultivo y la correcta asignación de virtud, a través de diversos mecanismos ${ }^{64}$.

Para nuestro propósito de mostrar el papel -instrumental - de la virtud en el republicanismo, basta con lo recorrido hasta aquí. La ley (justa) es la garantía de la libertad, de que nadie estará sometido a la voluntad arbitraria de nadie. Ley justa que sólo puede ser el resultado de una democracia máximamente participativa embridada - en sus posibles derivas tiránicas- por una deliberación que, a su vez, requiere de la virtud cívica. Para el republicanismo, muy sumariamente, la democracia no deriva en tiranía cuando es resultado de un proceso deliberativo que sólo es realmente correcto cuando se asegura la máxima participación, que, a su vez, requiere de la virtud ciudadana. Una democracia de esa naturaleza asegura una ley justa que es la que impide la dominación arbitraria de la voluntad de los otros, el valor más importante para el republicanismo.

63 J. Bohman y W. Rehg (eds.), Deliberative Democracy, Cambridge, Mass., The MIT Press, 1997; J. Bohman, «The Survey Article: The Coming of Age of Deliberative Democracy», The Journal of Political Philosophy, 1998, núm. 4; J. Dryzek, J., Deliberative Democracy and Beyond, Cambridge, Cambridge U.P., 2000; J. Elster, 1998a (ed.), Deliberative Democracy, Cambridge, Cambridge U.P., 1998; S. Macedo (ed.), Deliberative Politics, Oxford, Oxford U.P., 1999; J. L. Martí, Autogobierno deliberativo: una defensa de la democracia deliberativa participativa, Tesis doctoral, Univ. Pompeu i Fabra, 2004; A. Gutmann y D. Thompson, Why Deliberative Democracy?, Princeton, Princeton U.P., 2004.

$64 \mathrm{Al}$ menos existen tres mecanismos: a) la participación economiza las necesidades de virtud (de omnisciencia) al corregir los sesgos cognitivos (aparecen datos y razones y han de exponerse y justificarse) y con ello mejora las condiciones de la deliberación; $b$ ) la participación favorece la identificación de virtud al disminuir la asimetría informativa, proporciona mayores criterios de evaluación y permite detectar y, por tanto, alentar la virtud de los representantes que saben que sus (buenos) comportamientos pueden ser reconocidos; c) la participación incrementa la "producción» de virtud en tanto con el aumento de las posibilidades abiertas de participar propicia crecimiento de las disposiciones públicas: si hablo y me siento atendido, tengo razones para seguir participando. 


\section{Para concluir: sobre las reconstrucciones del republicanismo}

A lo largo de la historia, con la palabra «república» se han designado asuntos bien diferentes: la política, el Estado, el régimen político, la actividad pública, la comunidad de los ciudadanos, el bien común, entre otros ${ }^{65}$. Uno de los founding fathers, John Adams, que dedicó tres volúmenes al asunto, resignadamente, acabó por reconocer que no era fácil dotar de significado inequívoco a la palabra «república» ${ }^{66}$. Y hace bien poco, uno de los historiadores que estuvieron en el origen de la revitalización del republicanismo, al repasar el debate que él mismo desencadenó hace bastante más de treinta años, concluía: «Las rudimentarias categorías que los historiadores inventamos - "republicanismo" y "liberalismo" - se han diluido» 67 .

Aunque quienes han tomado el testigo del debate entre republicanismo y liberalismo, los filósofos y constitucionalistas, no parecen compartir la resignación de los historiadores ${ }^{68}$, lo cierto es que, miradas las cosas de cerca, las unanimidades son escasas. Por más que no exista presentación del republicanismo que no arranque marcando la frontera con el liberalismo, esa frontera parece ser la misma para todos: los teóricos del republicanismo, cuando perfilan el ideal republicano en contraposición al liberalismo, no parecen coincidir en la anatomía conceptual ni de uno ni de otro. Cada uno de ellos enfatiza un aspecto diferente del liberalismo: la democracia indirecta (Arendt); los derechos como protección (Pocock); la democracia negociadora (Sunstein); la libertad negativa (Pettit); la neutralidad del Estado y la elección «autónoma» de los propios fines (Sandel). Y, en consecuencia, cada cual pone el acento en un «principio» distinto al dibujar el republicanismo: la autorrealización y la participación (Arendt); la virtud y los deberes cívicos (Pocock); la deliberación (Sunstein); la libertad (Pettit); el autogobierno y el patriotismo (Michael Sandel). Lo cierto es que hay

${ }^{65}$ Cf. D. Rodgers, «Republicanism: the Career of a Concept», Journal of American History, junio de 1992.

${ }^{66}$ A Defence of the Constitutions of Government of the United States of America, 3 vols., (1794), vol. 3, p. 139, citado por D. Wootton, «Introduction: The Republican Tradition: From Commonwealth to Common Sense», en D. Wootton, Republicanism, Liberty, and Commercial Society, 1649-1776, Stanford, Stanford U.P., 1994, p. 6.

67 G. Wood, en una polémica («Machiavellian Moments») con J. G. A. Pocock, en las cartas al director de The New York Review of Books, núm. 16, de 19 de octubre de 2000. En el mismo sentido, Ch. Nador, «Aristotle and the Republican Paradigm: A Reconsideration of Pocock's, Machiavellian Moment», The Review of Politics, 58, 4, 1996, p. 680. Asimismo el artículo citado de D. Rodgers; D. McCoy, «Introduction», en M. Klein, R. Brown y J. Hench, The Republican Synthesis Revisited, Worcester, 1992. Y en un sentido menos histórico, polemizando con Sandel, W. Kymlicka, «Liberal Egalitarianism and Civic Republicanism: Friends or Enemies», en Politics in the Vernacular, Oxford, Oxford U. P., 2000.

${ }_{68}$ Con todo, el impacto entre éstos ha sido mucho menor que entre los historiadores, como ha recordado R. Goodin, «Folie Républicane», Annual Review of Political Science, núm. 6, 2003. 
republicanismos para todos los gustos ${ }^{69}$. Y lo mismo se puede decir del liberalismo ${ }^{70}$.

¿Quiere eso decir que el diagnóstico de Wood es acertado? ¿Carece de fundamento la oposición entre liberalismo y republicanismo? No estoy seguro de que las cosas sean así. Pero seguramente sí que hay razones para la prudencia al abordar las tareas de reconstrucción analítica. El republicanismo no es la mecánica clásica. Las tradiciones políticas conforman una suerte de sentina en donde, en un mar de debates circunstanciales marcados por conflictos de interés, se depositan no siempre con orden ni trabazón jerarquizada principios, tesis políticas y propuestas institucionales ${ }^{71}$. Aunque lo que hoy entendemos por átomo o gen tiene muy poco que ver con las ideas de Dalton o Mendel, nuestras teorías actuales se han ido perfilando a partir de las suyas, con clara conciencia de estar intentando resolver los retos en los que ellos encallaron. Nada de eso sucede con ideas como las de libertad, nación o

${ }^{69}$ En efecto, hay republicanismos comunitarios (M. Sandel, Democracy's Discontent, op. cit.) y liberales (P. Pettit, Republicanism, op. cit.); plebeyos y aristocráticos (D. Carrithers, «Not So Virtuous Republicans», Journal of the History of Ideas, 52, 21, 991); participativos (A. Fraser, The Spirit of the Laws, Toronto, University of Toronto Press, 1990) y defensores de la división de poderes y la Constitución (C. Sunstein, «Beyond the republican revival», The Yale Law Review, núm. 97; con acentos patrióticos, en un sentido muy especial, (M. Viroli, For Love to the Country, Oxford, Oxford U.P., 1995; D. Miller, On Nationality, Oxford, Oxford U.P., 1997) y críticos de todo asomo de patria (Habermas). Hay discrepancias en asuntos de enorme importancia: el papel de la deliberación, de la representación, de la división de poderes, la idea de libertad, las necesidades de virtud, el grado de comunidad, etc. A lo que se añade una genealogía disputada entre quienes miran a Grecia (P. Rahe, Republics Ancient and Modern, III vols. Chapel Hill, University of North Carolina Press, 1994), quienes miran a America (G. Wood, The Creation of American Republic 1776-1787, op. cit.), a las repúblicas italianas (J. Pocock, The Machiavellian Moment, Princeton, Princeton U.P., 1975), a Francia (C. Nicolet, L'idée republicaine en France (1789-1924), París: Gallimard, 1982; P. Rosanvaillon, Le peuple introvable. Histoire de la représentation démocratique en France, París: Gallimard, 1998; La démocratie inachevée. Histoire de la souveraineté du peuple en France, París, Gallimard, 2000, y, aun, al cristianismo, Milton; ver asimismo, A. Black, «Christianity and Republicanism», American Political Science Review, 91, 3. 1997. Para seguir el itinerario del concepto, D. Rodgers, art. cit., y P Rahe, op. cit. Un breve repaso de ese debate en la introducción a F. Ovejero, J. L. Martí y R. Gargarella (comp.), Nuevas ideas republicanas, Barcelona, Paidós, 2003.

${ }^{70} \mathrm{Si}$ volvemos la mirada hacia el lado liberal los trazos no son tampoco inequívocos. Importantes teóricos liberales, defienden tesis muy queridas para el republicanismo: la primacia de la democracia (Waldron), la autonomía (Raz), la autorrealizacion («el reto» de Dworkin), la participación ciudadana (Ackerman), la virtud cívica (Macedo). Incluso, el propio Hayek, con su insistencia en la independencia, en la ley como garantía contra la arbitrariedad (sobre todo de las mayorías). (Después de todo, Hayek consideraba a Cicerón «la principal autoridad del moderno liberalismo», The Constitution of Liberty, Londres, Roudledge, 1960, pp. 166-167). Distintos liberalismos y republicanismos que coinciden en tesis políticas e institucionales en F. Ovejero, «Dos democracias, distintos valores», J. Rubio Carracedo, J. M. Rosales y M. Toscano (eds.), «Educar para la ciudadanía», Contrastes, Suplemento 8, 2003, pp. 45 ss.

71 Como ha escrito P. Springborg: «reducir el republicanismo romano a las ideas expuestas por los historiadores y oradores que fueron sus abogados, es sintetizar una tradición institucional y legal viva de una manera altamente selectiva», «Republicanism, Freedom from Domination, and the Cambridge Contextual Historians», Political Studies, 2001, núm. 49, p. 854. 
democracia ${ }^{72}$. Rousseau no creía cultivar en una tradición de teoría o filosofía política «republicana»y, desde luego, no entendía su obra como un intento de resolver los problemas que Aristóteles o Maquiavelo habían planteado. Para el ginebrino vale lo que otros han recordado para otros clásicos: «Locke no escribió los Dos tratados para ser liberal, más que Burke escribió Las reflexiones sobre la revolución en Francia para ser conservador» ${ }^{73}$.

Todo eso es cierto y conviene no olvidarlo ${ }^{74}$. Con frecuencia las «reconstrucciones racionales» de la historia de las instituciones o de las ideas políticas recalan en una suerte de aguado hegelianismo en donde a las secuencias históricas se les impone una imposible horma inferencial, una relación de deducibilidad. Ahora bien, ese reconocimiento en nada afecta a la más que justificada necesidad de pulimentado conceptual. De hecho, su propia pertinencia reposa en la posibilidad de hacer distinciones entre las tradiciones. La afirmación de que la situación X o las ideas de $\mathrm{Y}$ participan de distintas fuentes sólo tiene sentido si podemos distinguir entre las distintas fuentes. La historia, seguramente, se parece más a un gazpacho que a una ensalada, pero no hay que olvidar que el sabor - y la propia existencia- del gazpacho es imposible sin el tomate, el aceite y el pimiento.

En las páginas anteriores, amparándome en esa inevitabilidad, he abordado esas inexcusables tareas cartográficas intentando capturar a partir de los principios más frecuentemente invocados - y, en lo posible, con cierta jerar-

72 El caso paradigmático es la idea de «nación». Buena parte de los problemas de la «definición» derivan de la mirada de los estudiosos del nacionalismo, quienes, a la hora de caracterizar al grupo, asumen el punto de vista - adoptan el uso de nación- del propio grupo o más exactamente, de quienes se denominan a sí mismos nacionalistas: hay un conjunto de individuos (los nacionalistas) que dicen que otro conjunto de individuos (más numeroso) es una nación, por tanto, este segundo conjunto constituye una nación. Circunstancia que se muestra con particular nitidez en los usos normativos de «nación», aquellos que, en rigor, no apuntan a ninguna «realidad ni científica ni social» y de los que, por tanto, «no puede predicarse su verdad o su falsedad», sino que «se refieren a grupos humanos a los que atribuyen la autoridad legítima sobre cierto ámbito». Simplemente es un arma de la batalla política, no una realidad por designar. Tomo estas consideraciones del excelente libro de L. Rodríguez Abascal, Las fronteras del nacionalismo, Madrid, Centro de Estudios Políticos y Constitucionales, 2000, p. 127.

73 J. Waldron, Liberal Rights, Cambridge, Cambridge U.P., 1993, p. 36.

74 Concurren aquí varias circunstancias: $a$ ) las instituciones se configuran en mitad de procesos históricos: son el resultado de ideas, de deliberaciones, $y$, no menos, de fuerzas, negociaciones y compromisos, de poderes de diversa naturaleza, que, por definición, guardan poca relación con las estrategias de justificación de las teorías normativas; $b$ ) las ideas y las prácticas políticas que inspiran las deliberaciones no se corresponden con teorías o filosofías políticas (los redactores de la constitución americana no estaban practicando «diseño institucional» republicano o liberal; simplemente, estaban resolviendo retos políticos, problemas que tenían que ver con intereses enfrentados: J. Elster, «Arguing and Bargaining in the Federal Convention and the Assemblee Constituante», Center for the Study of Constitutionalism in Eastern Europe, School of Law, University of Chicago, 1991; c) sea cual sea su proceso de gestación y las convicciones de sus inspiradores, las instituciones políticas están abiertas a distintas estrategias de fundamentación y, del mismo modo que se puede ser vegetariano por razones éticas, dietéticas o religiosas, una misma institución puede encontrar distintas justificaciones normativas. 
quía conceptual- el mayor número de propuestas institucionales y políticas cultivadas por la tradición republicana (y, en menor grado, la liberal). En particular, he tratado de destacar la importancia de la virtud para el republicanismo, para asegurar que la democracia propicie las leyes justas, la libertad. En ese sentido, el problema de la tensión liberal entre libertad y democracia, no tiene para el republicanismo la misma gravedad que para un liberalismo que excluye la posibilidad de la virtud. Rawls atina en su diagnóstico acerca de que sin virtud no hay democracia (buena) y en el carácter instrumental de la virtud. Ahora bien, reconocer la importancia de la virtud no quiere decir fundamentar normativamente el republicanismo en la virtud, en la «autorrealización de la naturaleza humana». El republicanismo no busca la autorrealización, sino las leyes justas que aseguran la libertad. Por eso mismo, no está justificado el temor de Rawls a que tengamos que «tutelar» una correcta naturaleza humana cuya «realización» es imposible garantizar. Los problemas son otros, la existencia de las disposiciones cívicas y de las condiciones materiales, sociales, para su desarrollo, para su «despliegue», por decirlo a lo Hegel. En el caso de que ni unas ni otras se den, quizá sólo quede resignarse pesimistamente a «la solución liberal». Una solución que no es tal, que, en realidad, es poco más que el reconocimiento de que hay que resignarse a convivir con el problema de Rawls, con la tensión entre libertad y democracia. 